\title{
High doses of ketamine to improve neuronal edema in subarachnoid hemorrhage: we should consider other undesirable organ targets
}

\author{
Patrick M. Honore*, Aude Mugisha, Luc Kugener, Sebastien Redant, Rachid Attou, Andrea Gallerani and \\ David De Bels
}

We read with interest the recent article by Santos et al. regarding the use of S-ketamine to decrease spreading depolarizations and improve cytotoxic neuronal edema in patients with aneurysmal subarachnoid hemorrhage [1]. They note that the active enantiomer $\mathrm{S}(+)$ ketamine is two times stronger than the racemic form and four times stronger than the $\mathrm{R}(-)$ enantiomer [1]. Further, they report that the upper therapeutically recommended dose of S-ketamine for sedation is $2 \mathrm{mg} / \mathrm{kg} \mathrm{BW} / \mathrm{h}$, but if deemed necessary, neuro-intensivists are using doses of up to $7 \mathrm{mg} / \mathrm{kg} \mathrm{BW/h}$. We would like to make some comments. S-ketamine is a non-competitive $N$-methyl-D-aspartate (NMDA) receptor ion channel blocker [2]. Its action is not limited to the brain, and as intensivists, we need to be mindful of the effects of ketamine upon other organs, especially when ketamine is used in high doses. Negative effects of these high doses have been described in the kidney $[2,3]$. Renal medullary oxygenation is strictly balanced by a series of control mechanisms, which match regional oxygen supply and consumption [2]. Failure of these controls renders the outer medullary region susceptible to acute or repeated episodes of hypoxic injury, which may lead to acute tubular necrosis (ATN), especially of the thick ascending limbs [2]. In the kidney, any increase in circulating catecholamines (especially epinephrine) will cause vasoconstriction via the alpha-receptors and activation of the reninangiotensin system [2]. As a result, despite normal renal blood flow, intramedullary ischemia may occur [2]. Increases in sympathomimetic hormones lead to renal cortical vasoconstriction, which is a compensatory attempt by the body to redistribute blood flow to the renal medulla, but in fact, it causes ischemia $[2,4] . S(+)$-ketamine is about three to four times more potent as an anesthetic than $\mathrm{R}(-)$-ketamine, but an equipotent dose of $\mathrm{S}(+)$-ketamine alone may show weaker norepinephrine and serotonin uptake inhibition than $\mathrm{R}(-)$-ketamine at anesthetic effective doses [2]. In a rat model of ischemia reperfusion of the kidney, high doses of $\mathrm{S}(+)$-ketamine induced a higher score of histological changes, with the rise in catecholamine blood concentration thought to be the likely cause [2]. Further studies are needed to investigate the relationship between high doses of ketamine and the risk of acute kidney injury (AKI). In the study of Santos et al., it would be interesting to know the data regarding the rate of AKI between the control group and the high-dose group.

This comment refers to the article available at https://doi.org/10.1186/ s13054-019-2711-3.

* Correspondence: Patrick.Honore@CHU-Brugmann.be

ICU Department, Centre Hospitalier Universitaire Brugmann-Brugmann

University Hospital, Place Van Gehuchtenplein, 4, 1020 Brussels, Belgium 


\section{Authors' response \\ High doses of ketamine to improve neuronal edema in subarachnoid hemorrhage: preliminary clinical data do not suggest an adverse effect on renal function \\ Edgar Santos, Sebastian Major, Renán Sánchez-Porras, and Jens P. Dreier}

Thank you for your kind interest in our work. Aneurysmal subarachnoid hemorrhage (aSAH) is indeed characterized by an impressive list of potential complications. Thus, aSAH is associated with $\sim 20$ relevant intracranial and $>30$ extracranial complications [5]. On top of this, there are numerous side effects of a wide range of medications. For our retrospective cohort study, we identified 66 patients from a prospectively collected database using prespecified criteria (32 from the University of Heidelberg, recruited 2004-2014, and 34 from CharitéUniversitätsmedizin Berlin, recruited 2005-2010) [1]. Laboratory values are readily available for the Berlin patients of whom 14 were treated with S-ketamine. The Acute Kidney Injury Network (AKIN) has defined AKI as abrupt (within $48 \mathrm{~h}$ ) reduction in kidney function leading to an absolute increase in serum creatinine of $\geq 0.3 \mathrm{mg} / \mathrm{dl}$, an increase in creatinine of $\geq 50 \%$, or a reduction in urine output $(<0.5 \mathrm{ml} / \mathrm{kg} / \mathrm{h}$ for $>6 \mathrm{~h})$ [6]. For the requested exploratory analysis, we here consider creatinine during the first 45 days after the initial hemorrhage (in total, 417 values, $12 \pm 9$ tests per patient). Based on this, 4 of 34 patients $(12 \%)$ developed AKI: 2 of $20(10 \%)$ without S-ketamine, 1 of 5 (20\%) with S-ketamine below, and 1 of 9 $(11 \%)$ with S-ketamine $>2 \mathrm{mg} / \mathrm{kg}$ body weight $(\mathrm{BW}) / \mathrm{h}$. In the latter patient, high-dose S-ketamine and mannitol treatment started on day 8 when she developed a dilated left pupil, decorticate posturing, intracranial pressure (ICP) above $20 \mathrm{mmHg}$, and computed tomography-proven transtentorial herniation. Serum creatine increased from 0.4 to $0.9 \mathrm{mg} / \mathrm{dl}$ between days 8 and 10 with full recovery thereafter. In parallel, a urinary tract infection with Escherichia coli was found and treated with ceftriaxone. In addition, the patient also suffered from arterial hypertension and systemic lupus erythematodes so that at least 5 potential etiologies of kidney damage coincided. In the follow-up (day 194), she was fully oriented but showed hemiparesis and mild aphasia (extended Glasgow Outcome Scale: upper severe disability). In the 9 patients, S-ketamine $>2 \mathrm{mg} / \mathrm{kg}$ $\mathrm{BW} / \mathrm{h}$ did not lead to significant creatinine changes overall (before S-ketamine, $0.65 \pm 0.17 \mathrm{mg} / \mathrm{dl}$; during high-dose S-ketamine, $0.68 \pm 0.18 \mathrm{mg} / \mathrm{dl}$; paired $t$ test; $P=0.443$ ). It should be taken into account that ketamine, in addition to its potentially beneficial effects on spreading depolarizations [7], also leads to reduction in ICP and to savings in catecholamines with potential kidney protection [8]. Nonetheless, although our data do not suggest that Sketamine increases the risk for AKI, renal function should be closely monitored.

\author{
Abbreviations \\ NDMA: N-Methyl-D-aspartate; ATN: Acute tubular necrosis; AKI: Acute kidney \\ injury \\ Acknowledgements \\ None. \\ Authors' contributions \\ $\mathrm{PMH}, \mathrm{SR}$, and DDB designed the paper. All authors participated in drafting \\ and reviewing. All authors read and approved the final version of the \\ manuscript.
}

Funding

None

Availability of data and materials

Not applicable.

Ethics approval and consent to participate

Not applicable.

Consent for publication

Not applicable.

Competing interests

The authors declare to have no competing interests.

Received: 5 May 2020 Accepted: 19 May 2020

Published online: 18 June 2020

References

1. Santos E, Olivares-Rivera A, Major S, Sánchez-Porras R, Uhlmann L, Kunzmann $\mathrm{K}$, et al. Lasting S-ketamine block of spreading depolarizations in subarachnoid hemorrhage: a retrospective cohort study. Crit Care. 2019; 23(1):427. https://doi.org/10.1186/s13054-019-2711-3.

2. Neto ER, Vianna PTG, Viero RM, Módolo NSP, Ganem EM, Braz JRC, Castiglia YMM. Influence of $\mathrm{S}(+)$-ketamine analgesia in renal intraoperative ischemia: histological study in rats. Acta Cir Bras. 2006;21(4):242-6. https://doi.org/10. 1590/s0102-86502006000400010.

3. de Resende MAC, Pantoja AV, Barcellos BM, Reis EP, Consolo TD, Módolo RP, et al. Ischemic postconditioning and subanesthetic S(+)-ketamine infusion: effects on renal function and histology in rats. Biomed Res Int. 2015;2015: 864902. https://doi.org/10.1155/2015/864902 Epub 2015 Aug 27.

4. Sear JW. Kidney dysfunction in the postoperative period. Br J Anaesth. 2005; 95:20-32.

5. Drenckhahn C, Windler C, Major S, Kang EJ, Scheel M, Vajkoczy P, et al. Complications in aneurysmal subarachnoid hemorrhage patients with and without subdural electrode strip for electrocorticography. J Clin Neurophysiol. 2016;33(3):250-9.

6. Mehta RL, Kellum JA, Shah SV, Molitoris BA, Ronco C, Warnock DG, et al. Acute Kidney Injury Network: report of an initiative to improve outcomes in acute kidney injury. Crit Care. 2007;11(2):R31.

7. Dreier JP. The role of spreading depression, spreading depolarization and spreading ischemia in neurological disease. Nat Med. 2011;17(4):439-47.

8. Von der Brelie C, Seifert M, Rot S, Tittel A, Sanft C, Meier U, et al. Sedation of patients with acute aneurysmal subarachnoid hemorrhage with ketamine is safe and might influence the occurrence of cerebral infarctions associated with delayed cerebral ischemia. World Neurosurg. 2017;97:374-82.

\section{Publisher's Note}

Springer Nature remains neutral with regard to jurisdictional claims in published maps and institutional affiliations. 